\title{
Reflections on Public Discussion in the Mass Media
}

\author{
Veikko Pietilä
}

Normative reflections upon democracy and the media have emphasized again and again that, in order to function properly, modern democracies require the media to provide "the means whereby the public debate" underpinning these societies "can take place" (Oreja et al. 1998: 9). Beetham and Boyle (1995: 13) think, for example, that the main task of the media, in addition to their 'watchdog' role, is their role as a forum for public debate whereby they also serve "the expression of public opinion to the government". According to Nordenstreng (1997: 18), in Scandinavian countries the "current 'functions' of the media" have been condensed into information function, critique function and forum function, the last one involving the media "to provide the representatives of different views the opportunity for publicity".

But why does the putative forum function of the media get such an emphasis? The answer is quite simple: public discussion has been regarded as a cornerstone for a viable democracy. From "the ancient Greek thought onwards, the general conception of democracy" has been based on specific "assumptions related to the communication sphere", one of them being that all "decisions are submitted to public discussions" (Splichal 1993: 5). Classically this principle was formulated by the $18^{\text {th }}$ century's progressive bourgeoisie in the demand that public opinion, being shaped in and through "the critical public debate among private people", ought to be "the only legitimate source" of decisions and legislation in general (Habermas [1962] 1989: 53, 54).

Department of Journalism \& Mass Communication, University of Tampere, FIN-33014 Tampere, tivepi@uta.fi

\section{Public Discussion as Face-to-Face Conversation}

One should note, however, that what was traditionally meant by public debate was face-to-face discussion in public. For instance, Peters (1999: 21) has stated that regardless of the emphasis Habermas puts on the press in the $18^{\text {th }}$ century's public sphere he still "avoids the implication" that the press is "the stage of public conversation". If the press "enables a wide-scale conversation to take place" (Peters 1995: 10), this is due above all to its working as "a catalyst of conversation" (Salmon \& Glasser 1995: 447). This view of the media as "the principal source of conversation", which takes place in fora safely outside of them, was formulated particularly by Tarde ([1898] 1969: 299). Also Dewey (1927) and Park (e.g. [1923] 1955 and [1940] 1955) approached the relationship between the media and public discussion from a similar perspective.

Some scholars see that the press and the media in general have ceased to reflect and animate public conversation and argument. Carey (1987), for one, thinks that once upon a time there was in the USA a public who kept a viable public discussion going. This public "was activated into a social relation by the news, and, in turn, the primary subject of the news was the public, the opinions being expressed in public by merchants, traders, citizens, and political activists of the time" (p. 10). However, with the turning of journalism into a reporting of what is happening in the remote world of high political decision making, citizens, "denied a public arena, became either consumers of politics or escapists from it" (Carey 1995: 391). This dissolved the public with the consequence that public discussion and debate went into eclipse. 
For Schudson (1997: 305), views like those of Carey stem from an assumption that "face-to-face conversation is a superior form of human interaction for which mass communication is a forever flawed substitute". Behind this acid remark lurks a doubt that in a modern democracy, whose scope oversteps multiply the "small scale social order in which assembly directly governs policy" (Peters 1995: 27), public discussion is difficult to conduct in a face-toface form. In brief, such a form of "public discourse seems impossible for the modern 'public"' (p. 16). This claim is clearly an overstatement, but, on the other hand, it is obvious that the media are needed in modern conditions not only as catalysts of conversation but also as arenas on which a more extensive public discussion can be carried out. This brings us back to the question of the forum function of the media.

\section{Public Discussion in the Media: Some Assessments}

It is interesting - and symptomatic of his bias to oral discussion - that Carey does not assess the performance of the media as arenas for public discussion. But perhaps there is not much to be assessed. At least such a state of affairs is indicated by demands that, for example, the newspaper should be "a common carrier for civic discourse, a medium for conversation among citizens rather than a conduit for professionally packaged information" (Pauly 1994: viii) or that journalism should offer a site "for readers to become more of a public - that is, for citizens to converse, discuss, argue, and engage each other in a dialogue of comparisons and futures" (Anderson et al. 1994: xxi). Such demands imply that currently the media fulfill their forum function badly.

Anderson et al. (1996: 163) do not deny the existence of public discussions in the media but regard them as "severely truncated". This is due to the prevailing journalistic practice which tends to focus on "celebrity representatives" with as "extreme points of view" as possible on the issues under debate (p. 163). Such a journalism is "more likely to polarize and entrench opinion rather than encourage discussion" (Anderson et al. 1994: 55). For journalism to be more conversational, it is suggested, among other things, that journalists should "rejoin civil society" and start talking to their recipients "as one citizen to another rather than as experts claiming to be above politics" (Hallin 1992: 20; cf. also Aufderheide 1991).
Some scholars see that the forum function of the media has been undermined through recent developments in the media system. With the growing commercialization of the media, "the citizen is appealed to as a private individual rather than as a member of the public, within a privatized domestic sphere rather than within that of public life" (Garnham 1986: 48). It is difficult to speak of a "rational public discourse" as the media supply becomes "more and more subordinate to audience-attracting and maintaining commercial logic" (Dahlgren 1991: 11). It is argued that a forum for a truly democratic public debate, which includes "as many of the existing views in a society on the relevant issues as possible", cannot be guaranteed without reconstituting the public service media as the core sector of the media world (Garnham 1986: 52; see also Curran 1991).

These critical remarks are certainly to the point in the sense that the way the media today attend to the forum function leaves much to be desired. On the other hand, frequently journalists or some outside parties raise to the media arena social issues, which give rise to diverse reactions and call forth editorials, letters to the editor, interview statements and other expressions of opinion from inside and outside of the media - that is, call into life something like a public discussion or debate. It is quite surprising that those criticizing normatively the media performance as a carrier of public discussion pay hardly any attention to this kind of phenomena. Perhaps such 'exchanges of opinion' do not fulfill the critics' criteria for discussion. In my view, however, such processes and the research they have inspired merit a closer inspection in terms of public discussion.

\section{"Moderation Rules OK" - A Case of Generating Public Discussion}

I shall begin with an example which, despite its circumscribed nature, serves to shed preliminary light on the subject. The use of alcohol and the policies of its regulation have composed quite a permanent theme in the Finnish public discussion. In bygone years, the Finnish State Alcohol Monopoly (Alko) used to take part in the discussion by organizing alcohol education campaigns attempting, through a strategic use of messages, to guide people's drinking habits in a healthier direction. Traditionally, such campaigns were focused on the individual level, and their effectivity was evaluated on the basis of their capacity to change individuals' behav- 
iour or, at least, attitudes in the desired direction. Often the campaigns proved quite ineffective in this respect.

In 1979 Alko launched an education campaign with the catchphrase "Moderation Rules OK". The campaign was organized so that it enabled the study of its effects on the social climate of opinion (Virtanen 1981a; Piispa 1982). That is, besides trying to impact people's attitudes or behaviour directly, the campaign attacked them also indirectly by attempting to foster public discussion in the mass media about the campaign themes. Regarding this aspect, the task of the research was to explore to what extent the campaign succeeded in arousing public discussion and how the debate actually proceeded. For Virtanen (1981a: 185), the impact of a campaign message

may be seen from its generativity, that is, its power to bring about differing reactions on the various planes of the climate of opinion: ideas, realizations and debate on the small group and individual level, and articles, comment and analysis on the part of the mass media.

Virtanen (p. 185) assumed that "the reactions generated by the campaign" may "constitute even long chains resulting in a widely ramifying bunch of discussions where the most significant disputes may concern issues barely touched upon in the initial message". In another context he added that, "especially within mass communication, the way of proceeding of the discussion may dismantle interesting linkages: which medium or which person reacts and in which way, what kind of front lines are generated and whom they consist of, etc." (Virtanen 1984: 15)

In exploring to what extent the "Moderation Rules OK" campaign stirred up reactions on the media arena, Virtanen (1981b: 34-56) found that the first reactions were separate comments which did not make up a discussion. Most of them were positive to the campaign except those of the temperance movement which were highly critical. Some time after the first reactions Helsingin Sanomat, the biggest Finnish daily, published a news story reporting the clash between the campaign and the temperance movement. This changed the situation from a noninteractive to an interactive in the sense that the subsequent media reactions engaged in polemics with one another: there emerged a discursive duell between liberals and the temperance movement.

\section{Defining Social Problems - the Constructionist Perspective}

This way of studying the possible effects of education campaigns has been called the 'generativity of education' approach (Hemánus et al. 1987). As Piispa (1997: 241-260) has remarked, the idea of 'generativity' comes close to the constructionist perspective on social problems according to which the problems do not result from objective social conditions but are constructed through collective definition. As Blumer (1971: 301) says, "the process of collective definition determines the career and fate of social problems, from the initial point of their appearance to whatever may be the terminal point in their course". This process takes place, at least in part, on different public arenas, the mass media being one of them (cf. Hilgartner and Bosk 1988).

The definition process has been specified by saying that problems are constituted by "claims-making activity" (Specter and Kitsuse [1977] 1987: 73). Mundanely, claims-making consists of

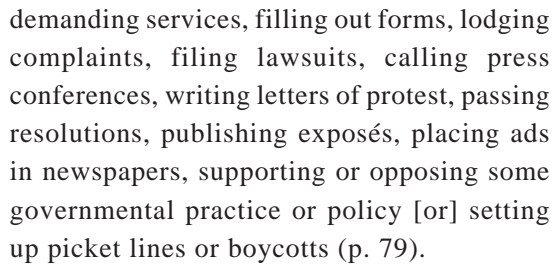
resolutions, publishing exposés, placing ads in newspapers, supporting or opposing some governmental practice or policy [or] setting up picket lines or boycotts (p. 79).

For example, by stepping forth and making a claim that a given condition is mischievous and must be improved, individuals and groups define it as a problem. With time, the initial claim may be "refined, and passed from one set of participants to another", and new participants may enter "the claimsmaking activity, redefine the problem, and shift the focus of activity" (p. 125). The problem becomes, simply, "the object of discussion, of controversy, of differing depictions, and of diverse claims" (Blumer 1971: 303). What this activity produces, is called "social problems discourse" or "social problems language game" (Ibarra and Kitsuse 1993: 32, 33).

Constructionist research on social problems does not concern, at least not in the first place, the objective conditions of some problem but the claimsmaking activity first establishing something as a problem. Yet, constructionists have disputed somewhat over the role of objective conditions in the re- 
search: strict constructionists exclude them altogether while contextual constructionists take them into account, for example, as grounds for judgment to what extent the claims made correspond to or deviate from those conditions (Best 1989 and 1993). But also the latter ones focus in the first place on the discourse or language game through which the problems under study develop. The objective conditions - which, of course, are themselves constructions produced through official statistics, social scientific research, etc. - come along then to check the validity of the claims or to "explain why particular claims emerge when they do" (Best 1989: 247).

For many constructionists, the claims-making processes have a career which passes various stages. Blumer (1971: 301) singled out five stages: “(1) the emergence of a social problem, (2) the legitimation of the problem, (3) the mobilization of action with regard to the problem, (4) the formation of an official plan of action and (5) the transformation of the official plan in its empirical implementation". Spector and Kitsuse ([1977] 1987: 137-158) proposed a four-stage model where the first stage covers the initial claims-making activity and the second the responses to it by some official organization or agency. The third and fourth stages "represent a kind of 'second generation' social problem in which the solutions to previous problems (the responses to previous demands) become the basis for renewed claims and demands" (p. 142).

Both Blumer and Specter and Kitsuse emphasized that movement from one stage to the next is highly problematic so that the process may break off at whichever stage. Even with this caveat, however, the validity of the stage models remains questionable (cf. Hilgartner and Bosk 1988). For example, Neuman (1998) found that the claims-making process he investigated did not follow Spector and Kitsuse's four-stage model. Rather, the "competing groups, including state actors, asserted claims many times in several forms with multiple definitions" (p. 329). Claims-making seems thus to be a "non-linear process of constructing meaning that gets enmeshed with other issues on multiple 'fronts"' (p. 329). Perhaps stage models should be conceived, at the most, as ideal types from which real processes deviate more or less.

Another important point in this context concerns the publicity of claims-making. As especially Hilgartner and Bosk (1988: 58) have stressed, social problems "must compete both to enter and to remain on public agenda". On the one hand, those making efforts to advance some putative conditions to the status of social problem, are in sore need of publicity because publicity is an indispensable resource for getting the problem candidate recognized generally as a real problem. On the other hand, publicity is a scarce resource since each public arena "has a carrying capacity that limits the number of social problems that it can entertain at any one time" ( $p$. 59). Problems having a foothold in public arenas are thus continually in danger of being dropped out.

Despite the necessity of publicity for the claimsmakers, not necessarily all of their activities take place in public. Even much of them may be carried out behind closed doors. But in so far as claims constituting a particular problem are made on public arenas, they compose something like a public discourse or debate. Public arenas "include the executive and legislative branches of government, the courts, made-for-TV movies, the cinema, the news media (television news, magazines, newspapers, and radio), political campaign organizations, social action groups, direct mail solicitations, books dealing with social issues, the research community, religious organizations, professional societies, and private foundations" (Hilgartner and Bosk 1988: 58-59). Here, the attention is on the mass media.

Given the points above, one would expect that there would be a lot of constructionist research exploring the claims-making activity in the media in terms of public discussion or debate. This seems not to be the case, though. Often the analyses of the media material have concentrated on other aspects than those constituting a discussion. Typical examples are Johnson's (1989) study of the role of horror stories, published by U.S. newspapers, in the construction of child abuse as a social problem, or Reinarman and Levine's (1989) analysis of how the U.S. media succeeded to stir up, in the latter part of the 1980s, a "crack scare" by reporting highly dramatized data on the use and the destructive effects of this drug. Neither study did approach the claimsmaking activity as a form of public discussion.

There are, of course, investigations which feature the claims-making activity as a discussion-like process. One example is Piispa's (1997) study concerning the definition activity in the press around the alcohol problem. There he posed his objective as follows (p. 248):

I will describe neither the concrete processes in defining alcohol as a problem, nor the interactions between the definers or the chains that their actions form, but the results of the processes: the basic definitions of the alcohol 
problem, and the designs of alcohol policy associated with them.

Piispa implies here, first, that what he studied was actually a public discussion consisting of interactions between actors, and, second, that it could have been studied as such. Yet, he himself was not interested in the discussion as such but only in what definitions it produced. In this way the discussion was reduced largely to its content. This did not, however, strip the process of its debate-like character altogether in Piispa's treatment. Namely by specifying the clashes between definitions put forth by different parties he enabled the reader to view the definition process as a discursive struggle on a public arena. A similar example is offered by Väliverronen (1996), who studied the clashing public discourses over the forest damages in Finland in the late 1980s.

Perhaps - as these examples indicate - one might consider public discussion on differing levels of generality. On a microscopic level, the discussion would consist of concrete utterances made by particular individuals and groups, while on a macroscopic level one would be dealing with more general discourses into which the concrete utterances can be condensed. On the microscopic level, the discussion would take place between individuals and groups; on the macroscopic level, again, between discourses. From this perspective, the above studies of Piispa and Väliverronen would represent the macroscopic approach to public discussion. But such an approach has been rare in the constructionist research, to speak nothing of a microscopic approach to public discussion.

\section{Where is the Public?}

There are surely many reasons why the constructionists have ignored the discussion-like nature of claims-making processes and concentrated instead, at the most, on their substantial results. This is quite understandable if one thinks, as Hakulinen (1997: $15)$, that "the word discussion brings in mind, in the first place, something substantial: a discussion is carried out over some subject matter'. Furthermore, if the constructionists are "primarily concerned with the definitional activities" (Troyer 1989: 53), then there are some grounds to focus on the content of the claims made and to leave the interactional aspect of the claims-making process aside.

In my view, however, this objective has unnecessarily narrowed the research by pushing the claimsmakers in the margins. Mauss (1989), for one, has tried to put them back in the focus by insisting that the construction of social problems ought to be theorized from the perspective of social movements. Instead of social movements, I would like to start with a certain notion of the term 'public'. The term itself has many meanings. Merely as a noun it denotes, first, something that is opposite to the private and the secret, but also, second, different human collectives. Price (1992: 35-43) has singled out five collectives or categories of people to which the term 'public' has been applied. From the broadest to the narrowest they reach from the whole population via the electorate and those who follow public affairs to active or issue publics, that is, to people who take part in public affairs or act on public issues or problems.

The concept of public as an active or issue public was developed especially within the study of collective behavior. This study is rooted in the late $19^{\text {th }}$ century's crowd psychology and, above all, in Gabriel Tarde's thinking. Unlike the other top name of crowd psychology, Gustave Le Bon, who saw only crowds in society, Tarde ([1901] 1969) made a distinction between the crowd and the public. While a crowd consists of people present at the same place at the same time, a public consists of people who are physically separate and whose unity is purely mental. This unity becomes established when a common medium, like a newspaper, arouses a conviction or passion simultaneously in the minds of a body of people. Beyond these distinctive features publics were, for Tarde, quite like crowds.

Robert E. Park ([1904] 1972) drew a tighter distinction between the crowd and the public. For him, they are constituted through different modes of interaction. Where "the crowd submits to the influence of a collective drive which it obeys without criticism", the public, which consists of people with clashing opinions, "is guided by prudence and rational reflection" (p. 80). Its specific mode of interaction is critical discussion purported to reconcile the conflict which initially called the public into being. Thus, where Tarde saw the public as being united by a common conviction or passion, Park regarded it as divided in opinion. A corollary is that Tarde saw publics as more or less permanent while Park saw them as temporary formations bound to dissolve sooner or later.

This line of thought continued via John Dewey (1927), Herbert Blumer ([1946] 1961 and [1947] 1965) and C. Wright Mills ([1956] 1995) onwards. Blumer ([1946] 1961: 373), for one, defined the public to refer "to a group of people (a) who are confronted by an issue, (b) who are divided in their ideas as to how to meet the issue, and (c) who en- 
gage in discussion over the issue". A public aspires to find an agreeable solution to the disputed issue or at least to form a public opinion to be brought into purview of those whose duty it is to act on the issue (Blumer [1947] 1965). In sum, the specific sense of the public, developed within the study of collective behavior, was that it is "a dispersed group of people interested in and divided about an issue" and "engaged in discussion of the issue", with the purpose of contributing to its solution (Turner and Killian 1972: 179).

A public defined in this way comes close to people engaged in claims-making activity. In such a case there is an issue, there are people who are interested in but divided about it, and there is discussion in the sense that people make claims with the apparent intention to influence the fate of the issue. Given this, one would have expected that at least Blumer would have taken advantage of the term 'public', in the sense he himself defined it in the 1940s, in his 1971 essay where he launched the idea of social problem definition "as collective behavior" (Blumer 1971: 298). But alas, he seems to have forgotten totally his earlier views. There is not a whit of public in this sense in his essay. This holds true also regarding the subsequent constructionist texts.

If the constructionists use the term 'public' at all, they refer with it to the passive onlookers to which the active claims-makers try to appeal. Statements claiming that social problems, as defined on different public arenas, are "presented to the public" (Hilgartner and Bosk 1988: 59), or that "claimants' discursive practices" are a means for "demarcating moral objects of relevance to a 'public", (Ibarra and Kitsuse 1993: 32), locate the public firmly outside of the nucleus taking actively part in the collective definition process. Where Blumer ([1946] 1961: 373 ) referred, in the 1940 s, with the term public to an active body of people, the body to which the constructionists refer with it is essentially a passively receiving one. In this way the term has been stripped of all its earlier dynamic characteristics.

It seems to me that without a view of the claimsmakers as a public constituted by a discursive mode of interaction, things like interaction and discussion do not seem to come easily to the fore. Spector and Kitsuse ([1977] 1987: 78), for ones, certainly see claims-making as "a form of interaction", but only in the sense of "a demand made by one party to another that something be done about some putative condition". In other words, they see claims-makers and the agencies, to whom claims are directed, as "interacting in claims-making activity" (p. 83), but fail to pay corresponding attention to the interaction among the claims-makers themselves.

The problems do not stop at this. Smith (1993: 329-330), for one, has noted the somewhat astonishing fact that the constructionist theory has seldom located the collective definition process of social problems explicitly in the public sphere. In fact, the whole idea of a public sphere, reproduced through public discussion, seems quite alien to this theory. Why may this be? One is, again, tempted to think that a reason for this is the theory's lack of a view of public as an actively discussing collective. As already stated, such a view would have been available in the concept of public developed within the traditional analysis of collective behavior - a concept that is a clear derivative from the classic democratic ideal of the public as a critically discussing body of people in the public sphere (cf. Habermas [1962] 1989).

This lacunae in the constructionist theory comes into sight in its view of the media, too. One problem is that, although "the press and media" are spoken of, they "are not explored as a medium integral to the social organization of a social problem", as Smith (1993: 330) has remarked with a reference to Spector and Kitsuse ([1977] 1987: 145). And the expositions, which pay more notice to the media (e.g. Schoenfeld, Meier and Griffin 1979, Schneider 1985: 221-223 and Maynard 1988: 322-325), seem to "carry an underlying view of mass communication processes as linear, flow or transmission oriented" (Hansen 1991: 447). The media are seen as platforms on which the advocates of various problems strive to step to make "claims to publics at large" (Gubrium 1993: 92). Such a view tends to forget that the processes making up the careers of social problems are "interactive and parallel, rather than unilinear", even in regard to the media (Hansen 1991: 454).

\section{What is Public Discussion in the Media Anyway?}

In spite of all this, there are analyses of media content, carried out both inside and outside of the constructionist camp, that have posed their object of study in terms of public discussion or that at least speak of it in these terms. In Finland, constructionist research includes, for example, Piispa's (1997) study on public discussion over alcohol policy and Väliverronen's (1996) study on public discussion over forest damages. Studies not based expressly on constructionism include, to give some 
examples, analyses of public discussion over nuclear energy and Finnish energy policy in general (Sänkiaho and Rantala 1987, Kantola, Haverinen and Peuhkuri 1993), over the question of Finland's membership with the EU (Heikkilä 1996 and 1998), and over Finnish strategies of moving into information society (Hintikka 1999).

What catches one's eye in these studies is that, even though they talk of their object as public discussion or debate, they do not define these terms or even characterize them any closer. The study of Kantola, Haverinen and Peuhkuri (1993) is an exception. Moreover, these studies do not analyze their objects as interactive processes, that is, as temporally developing bunches of interlinked speechacts. Instead, they concentrate on the contents of the discussions analysing, for example, what kind of standpoints there have been presented, how the standpoints are justified etc. In some cases this has only brought about a shift from the microscopic public discussion to the macroscopic 'discussion between discourses', but in most cases the consequencce has been the transformation of public discussions into collections of non-linked expressions of opinion. Thereby the mass media are approached not as fora for public discussion but, to resort to an old venerable catchphrase, as marketplaces of ideas.

Kantola, Haverinen and Peuhkuri (1993), who have reflected to some extent upon what public discussion might mean, define it as follows (p. 24):

\begin{abstract}
The concept of 'public discussion' can be comprehended as an interlocution between two or more social agents. This interlocution creates dialectically new realities into the consciousness of the actors as it gives rise to new states of affairs, standpoints, opinions, views, and arguments that often are something more than the initial separate utterance.
\end{abstract}

The researchers thus conceive public discussion, quite similarly as it was envisaged within the 'generativity of education' approach, as an interactively developing chain of public speech-acts. They imply, moreover, that this process may constitute a learning experience for the participants. Therefore, the study should pay due notice to "how the repetition of messages and, on the other hand, the entering of new messages in the discussion influence the way in which the discussants see the reality" (p. 25). Naturally there are also public discussions which are conducted from fixed positions and which do not instigate any changes among the discussants.
When considering the mass media as an arena for public discussions, Kantola and his colleagues remark that even such material, which appears as pure information, may be a part of a discussion. In fact, public discussion may be carried on in all "contents of mass communication, excluding perhaps only advertising" (p. 2). Their promising starting points notwithstanding, the researchers did not analyze their material - news and op-ed writings concerned with questions of Finnish energy policy in terms of an interactive, temporally developing public discussion. The reason for this seems to be the lack of an adequate methodology - "the description of a discussion as a process consisting of different phases requires the content analytical methods to be developed to a more dynamic direction", the researchers state (p. 92).

Anyway, the views of Kantola and his colleagues, as well as those developed already earlier within the 'generativity of education' approach, offer fruitful insights into public discussion in the mass media. Here I would like to add to them one important point. Splichal (1997: 111), when reflecting upon public opinion, once referred to Tönnies' view according to which public opinion is "the 'opinion of the public'". We might say similarly that public discussion is the discussion of the public. The term 'public' is utilized here naturally in the same meaning as it was used within the traditional analysis of collective behavior. Remember that the mode of interaction, which constitutes a public in this sense, is discussion taking place in some public sphere, be it specific such as a meeting or general such as the mass media.

To elaborate this a bit: the public in this sense is not a pregiven group whose members would enter into discussion with each other, but a collective which first begins to develop in and through discussion. For example, a claims-making public starts to take form only after somebody has initiated it by making a claim in public, and its formation takes place in tandem with the public reactions - both supportive and opposing - which this initial claim calls forth. There is thus a mutual constitution process: the discussion and the public condition reciprocally each other. In fact, we can say, twisting Dewey (1916: 15) a little, that a public does not only exist by discussion "but it may be fairly said to exist" in discussion.

One could perhaps consider a public discussion as a "phenomenon comparable with a game" (Kantola, Haverinen and Peuhkuri 1993: 11), where the members of the discussing public act as the 
players. Each contribution to the discussion would then be a move in the game. For example, in the trajectory of a claims-making public the initial claimmaking is the first move which calls other players to come along and to contribute to the development of the game with their moves. A claims-making process might thus be seen as a complex, temporally shifting constellation of moves and countermoves. It should be noted that this idea is a small-scale application of the more general sociological view that interaction is like playing a game (for a more elaborate application of this view, see K. Pietilä and Sondermann 1994; cf. also 1997).

One must ask, however, how far the metaphor of game is valid in this case. Consider, for example, a set of contributions which concern the same issue and which have appeared during a certain period in different media. One can think that each contribution is elicited by one or more preceding contributions and is, therefore, a response to them in quite the same sense as a move on checkboard is a response to preceding moves. The critical question is, however, to what extent the contributions disclose which previous 'moves' they respond to and, consequently, to what extent the set in question can be reconstructed as a series of interlinked 'moves'. This question gives reason to reflect once more upon why studies posing their object in terms of public discussion have nonetheless slid over the discussions as interactive processes.

I have already presented some possible reasons for this. Here comes a further possibility: maybe it is simply so that what would in principle be an interactive process does not appear as such in the contents of the media. First, the discussants themselves may consider it unnecessary to relate their contributions to those which have elicited them. After all, what counts most for each one is what he or she him- or herself has to say. Second, in cases where the contributions are filtered through journalists, the journalists may report only the most striking opinions and dismiss the rest of the material, including all intertextual hints at others' contributions which it may include. In both cases, the contributions would be shorn of all marks of interactivity, which would make them appear as insulated monologues instead parts of a dialogue (cf. Heikkilä and Kunelius 1997: 9-10). ${ }^{1}$ A public discussion on the net would probably be different in this respect.

Moreover, there may be cases which cannot be characterized as discussions but, at the most, as quasi- or pseudo-discussions. For example, if an intervention, such as the "Moderation Rules OK" campaign, elicits separate comments, these com- ments do not make up a real discussion although they are responses to the intervention. Also a public exchange of opinions, conducted from fixed positions and iterating only the entrenched opinions of the discussants, is more like a quasi-discussion than a genuine one, because such an exchange of opinions do not amount to a genuine interaction but a sort of interreaction. At least one can say that there are different types of public discussions - for example, such that get nowhere and such that proceed. Of course, one and the same discussion may vary between stages of stagnation and stages of progress.

The above notion of discussion rests on the view that its defining characteristics are interactivity and dialogical nature. That is, in order to compose a discussion the utterances must react or relate to one another at least to some degree. But to what degree? And must every utterance do so? Let us imagine a meeting where every participant expresses his or her opinion about the issues under discussion without relating their say to the others' utterances. Is this a discussion or not? If it is not, how many participants must take notice of what others say in order there to be a discussion? Is the discussion composed only of those utterances that do take notice of the others' utterances? How can it be ascertained that a given utterance takes or does not take notice of what others say? As can be seen, it is not easy to say when there is a discussion and when not - even though one would feel that few other things can be identified so readily as a discussion.

\section{Concluding Remarks}

I started this essay by calling attention to the importance which those approaching democracy and the media from a normative perspective have granted to the media as arenas for public discussion. Compared with this emphasis, it is quite amazing that as I have tried to show - the performance of the media as such arenas is poorly studied and that even the meaning of public discussion has remained obscure. Perhaps public discussion belongs to those phenomena which are too familiar and which, due to this, seem so simple and straightforward as to warrant no further reflection. This might explain why, at least in Finland, the only criterion for the use of the term 'public discussion' seems to be that the instance in question has something to do with publicity.

If public discussion is as vital for democracy as it has been argued to be - and I think it is albeit not necessarily in the forms in which it is conducted today - it merits to be taken seriously also outside the 
normative circles and given definite room on both theoretical and empirical agendas. Theoretically, at least, one can insist that public discussion corresponds to a communicative situation which Krippendorff (1969: 91) has characterized as

comprising several communicators, each pursuing its own objectives. The [evolving] text [..] cannot be considered as single consistent discourse but as representing a pattern of linguistic and non-linguistic interactions between parties, a chronology of exchanges among purposive communicators. Each of these exchanges is generated by one party and directed to other parties. Being a response to previous exchanges, each of them is [located at] a point in time relative to each other.

An important question is whether or not public discussions are researchable as such processes of interaction. The problem is, as indicated already above, that although exchanges are responses to earlier exchanges and directed to other parties of the discussing public, they may not contain clear intertextual marks of this. This question, however, cannot be answered on a theoretical level but requires empirical inquiries into real discussions. If their study as in- teractive processes proves possible, the way is open to the investigation of questions which the research of public discussion has hitherto not touched upon as, for example, whether or not the discussants are willing and able to take lessons from one another as the discussion proceeds.

Last but not least: theoretical thinking and empirical research on public discussion cannot make real progress without the rehabilitation of the term 'public' in the sense it had in the traditional theory of collective behavior. Openings toward this direction has already been made within the so called public journalism movement (see Rosen 1994, Heikkilä and Kunelius 1996 and Coleman 1997). Public discussion should be comprehended as the discussion of such a public. The view that those taking part in a public discussion compose a public, would keep in mind that what is at stake is an interactive and social process even though not all cases would be researchable as such processes. Moreover, the term would keep the empirical research connected to two sources from which it can absorb vigour - to the theories of publicness and public sphere, on the one hand, and to the democratic ideals implied by these theories, on the other.

\section{Note}

1. Even if the contributions appearing in the media over some issue would actually relate dialogically to each other, it is not sure that the audience would realize this and see the contributions as making up a discussion.

\section{References}

Anderson, Rob, Robert Dardenne and George M. Killenberg (1994) The Conversation of Journalism: Communication, Community, and the News. Westport, CT: Praeger.

Anderson, Rob, Robert Dardenne and George M. Killenberg (1996) The American Newspaper as the Public Conversational Commons. Journal of Media Ethics, 11:3, 159-165.

Aufderheide, Patricia (1991) Public Television and the Public Sphere. Critical Studies in Mass Communication, 8:2, 168-183.

Beetham, David and Kevin Boyle (1996) Introducing Democracy: 80 Questions and Answers. Cambridge: Polity Press.

Best, Joel (1989) Afterword. Extending the Constructionist Perspective: A Conclusion - and an Introduction. In Joel Best (ed.) Images of Issues: Typifying Contemporary Social Problems, 243-253. Hawthorne, NY: Aldine de Gruyter.

Best, Joel (1993) But Seriously Folks: The Limitations of the Strict Constructionist Interpretation of Social Problems. In James A. Holstein and Gale Miller (eds.) Reconsidering Social Constructionism: Debates in Social Problems Theory, 129-147. Hawthorne, NY: Aldine de Gruyter.

Blumer, Herbert ([1946] 1961) The Crowd, the Mass, and the Public. In Wilbur Schramm (ed.) The Process and Effects of Mass Communication, 363-379. Urbana: University of Illinois Press.

Blumer, Herbert ([1947] 1965) Public Opinion and Public Opinion Polling. In Daniel Katz et al. (eds.) Public Opinion and Propaganda: A Book of Readings, 7078. New York: Holt, Rinehart and Winston.

Blumer, Herbert (1971) Social Problems as Collective Behavior. Social Problems, 18:3, 298-306.

Carey, James W. (1987) The Press and the Public Discourse. The Center Magazine, 20:2, 4-16.

Carey, James W. (1995) The Press, Public Opinion and Public Discourse. In Theodore L. Glasser and Charles T. 
Salmon (eds.) Public Opinion and the Communication of Consent, 373-402. New York: Guilford Press.

Coleman, Renita (1997) The Intellectual Antecedents of Public Journalism. Journal of Communication Inquiry, 21:1, 60-76.

Curran, James (1991) Mass Media and Democracy: A Reappraisal. In James Curran and Michael Gurevitch (eds.) Mass Media and Society, 82-117. London: Edward Arnold.

Dahlgren, Peter (1991) Introduction. In Peter Dahlgren and Colin Sparks (eds.) Communication and Citizenship: Journalism and the Public Sphere in the New Media Age, 1-24. London: Routledge.

Dewey, John (1916) Democracy and Education. New York: Macmillan.

Dewey, John (1927) The Public and Its Problems. New York: Henry Holt.

Garnham, Nicholas (1986) The Media and the Public Sphere. In Peter Golding, Graham Murdock and Philip Schlesinger (eds.) Communicating Politics, 37-53. New York: Holmes \& Maier.

Gubrium, Jaber F. (1993) For a Cautious Naturalism. In James A. Holstein and Gale Miller (eds.) Reconsidering Social Constructionism: Debates in Social Problems Theory, 89-101. Hawthorne, NY: Aldine de Gruyter.

Habermas, Jürgen ([1962] 1989) The Structural Transformation of the Public Sphere: An Inquiry into a Category of Bourgeois Society. Cambridge, MA: The MIT Press.

Hakulinen, Auli (1997) Johdanto (Introduction). In Liisa Tainio (ed.) Keskustelunanalyysin perusteet (The Foundations of Conversation Analysis) 13-17. Tampere: Vastapaino

Hallin, Daniel C. (1992) The Passing of the "High Modernism" of American Journalism. Journal of Communication, 42:3, 14-25.

Hansen, Anders (1991) The Media and the Social Construction of the Environment. Media, Culture \& Society, 13:4, 443-458.

Heikkilä, Heikki (1996) “Teemmepä kumman päätöksen tahansa...": EU-keskustelun rakentuminen valtavirtamediassa 1992-1994 ("Whichever Decision We Make...": The Construction of the Discussion over the EU in the Mainstream Media, 1992-1994). In Ullamaija Kivikuru (ed.) Kansa euromyllyssä (The People in the Euro Mill) 65-106. Helsinki: Helsinki University Press.

Heikkilä, Heikki (1998) Luottamus ja epäluulo: valtion ja kansalaisuuden ideat Helsingin Sanomain EUkeskustelussa (The Trust and the Mistrust: The Ideas of State and Citizenship in the Discussion over EU in Helsingin Sanomat). In Marja Keränen (ed.) Kansallisvaltion kielioppi (The Grammar of the Nation State) 90-108. SoPhi 28. Jyväskylä: Jyväskylän yliopistopaino.

Heikkilä, Heikki and Risto Kunelius (1996) Public Journalism and Its Problems: A Theoretical Perspective. Javnost/The Public, 3:3, 81-95.
Heikkilä, Heikki and Risto Kunelius (1997) Julkisen journaslismin äärellä (Access, Dialogue, Deliberation). Tiedotustutkimus, 20:4, 4-21.

Hemánus, Pertti et al. (1987) Virittävyyden ongelma (The Problem of Generativity). Tampereen yliopiston tiedotusopin laitoksen julkaisuja, C:9.

Hilgartner, Stephen and Charles L. Bosk (1988) The Rise and Fall of Social Problems: A Public Arenas Model. American Journal of Sociology, 94:1, 53-78.

Hintikka, Kari A. (1999) Puheenvuorojen kirjasto 2: keskustelua tietoyhteiskuntastrategiasta (The Library of Contributions 2: Discussion over the Strategy of Information Society). Sitra 219.

Ibarra, Peter R. and John I. Kitsuse (1993) Vernacular Constituents of Moral Discourse: An Interactionist Proposal for the Study of Social Problems. In James A. Holstein and Gale Miller (eds.) Reconsidering Social Constructionism: Debates in Social Problems Theory, 25-58. Hawthorne, NY: Aldine de Gruyter.

Johnson, John M. (1989) Horror Stories and the Construction of Child Abuse. In Joel Best (ed.) Images of Issues: Typifying Contemporary Social Problems, 519. Hawthorne, NY: Aldine de Gruyter.

Kantola, Ismo, Risto Haverinen and Timo Peuhkuri (1993) Energiatietämys julkisessa keskustelussa (Energy Related Cognizance in Public Debating). Helsingin yliopiston sosiaalipsykologian laitoksen energiajulkaisuja 8/93.

Krippendorff, Klaus (1969) Models of Messages: Three Prototypes. In George Gerbner et al. (eds.) The Analysis of Communication Content, 69-106. New York: John Wiley \& Sons.

Mauss, Armand L. (1989) Beoynd the Illusion of Social Problems Theory. In James A. Holstein and Gale Miller (eds.) Perspectives on Social Problems, vol. 1, 19-39. Greenwich, CT: JAI Press.

Maynard, Douglas W. (1988) Language, Interaction and Social Problems. Social Problems, 35:4, 311-334.

Mills, C. Wright ([1956] 1995) The Mass Society. In Robert Jackall (ed.) Propaganda, 74-101. Houndmills: The Macmillan Press.

Neuman, W. Lawrence (1998) Negotiated Meanings and State Transformation: The Trust Issue in the Progressive Era. Social Problems, 45:3, 315-335.

Nordenstreng, Kaarle (1997) The Citizen Moves from the Audience to the Arena. Nordicom Review, 18:2, 1320.

Oreja, Marcelino et al. (1998) The Digital Age: European Audiovisual Policy. Report from the High Level Group on Audiovisual Policy. Brussels: European Commission.

Park, Robert E. ([1904] 1972) The Crowd and the Public and Other Essays (ed. by Henry Elsner, Jr.). Chicago: The University of Chicago Press.

Park, Robert E. ([1923] 1955) The Natural History of the Newspaper. In The Collected Papers of Robert Ezra Park, vol. III: Society, 89-104. Glencoe, IL: The Free Press. 
Park, Robert E. ([1940] 1955) News as a Form of Knowledge. In The Collected Papers of Robert Ezra Park, vol. III: Society, 71-88. Glencoe, IL: The Free Press.

Pauly, John J. (1994) Foreword: Making the News Relevant to Democracy. In Rob Anderson et al., The Conversation of Journalism, vii-xvii. Westport, CT: Praeger.

Peters, John Durham (1995) Historical Tensions in the Concept of Public Opinion. In Theodore L. Glasser and Charles T. Salmon (eds.) Public Opinion and the Communication of Consent, 3-32. New York: Guilford Press.

Peters, John Durham (1999) Media, Conversation, and Democracy. Paper presented in the seminar "Citizenship and/in Journalism" at the University of Tampere, April 23 ${ }^{\text {rd }}$ and $24^{\text {th }} 1999$.

Pietilä, Kauko and Klaus Sondermann (1994) Sanomalehden yhteiskunta (The Newspaper's Society). Tampere: Vastapaino.

Pietilä, Kauko and Klaus Sondermann (1997) Torn Between Society and Individual. Associations: Journal for Social and Legal Theory, 1:1, 11-23.

Piispa, Matti (1982) Virittääkö valistus? (Does Education Have Generative Effects?). Tiedotustutkimus, 5:3, 41-50, 76.

Piispa, Matti (1997) Valistus, holhous, suojelu: tutkimus alkoholipoliittisesta ja tupakkapoliittisesta mielipideilmastosta (Popular Education, Paternalism, Protection: Public Discourse on Alcohol Policy and Tobacco Policy in Finland). Acta Universitatis Tamperensis 564

Price, Vincent (1992) Communication Concepts 4: Public Opinion. Newbury Park, CA: Sage.

Reinarman, Craig and Harry G. Levine (1989) The Crack Attack: Politics and Media in America's Last Drug Scare. In Joel Best (ed.) Images of Issues: Typifying Contemporary Social Problems, 115-137. Hawthorne, NY: Aldine de Gruyter.

Rosen Jay (1994) Making Things More Public: On the Political Responsibility of the Media Intellectual. Critical Studies in Mass Communication, 11:4, 363-388.

Salmon, Charles T. and Theodore L. Glasser (1995) The Politics of Polling and the Limits of Consent. In Theodore L. Glasser and Charles T. Salmon (eds.) Public Opinion and the Communication of Consent, 437-458. New York: Guilford Press.

Schneider, Joseph W. (1985) Social Problems Theory: The Constructionist View. Annual Review of Sociology, vol. 11, 209-229.

Schoenfeld, A. Clay, Robert F. Meier and Robert J. Griffin (1979) Constructing a Social Problem: The Press and the Environment. Social Problems, 27:1, 38-61.

Schudson, Michael (1997) Why Conversation is Not the Soul of Democracy. Critical Studies in Mass Communication, 14:4, 297-309.
Smith, Dorothy E. (1993) "Literacy" and Business: "Social Problems" as Social Organization. In James A. Holstein and Gale Miller (eds.) Reconsidering Social Constructionism: Debates in Social Problems Theory, 327-346. Hawthorne, NY: Aldine de Gruyter.

Spector, Malcolm and John I. Kitsuse ([1977] 1987) Constructing Social Problems. Hawthorne, NY: Aldine de Gruyter.

Splichal, Slavko (1993) Searching for New Paradigms: An Introduction. In Slavko Splichal and Janet Wasko (eds.) Communication and Democracy, 3-18. Norwood, NJ: Ablex.

Splichal, Slavko (1997) Public Opinion as a Panopticon: A Critique of the Spiral of Silence. In Jan Servaes and Rico Lie (eds.) Media \& Politics in Transition: Cultural Identity in the Age of Globalization, 111125. Leuven: Acco.

Sänkiaho, Risto and Harri Rantala (1987) Ydinvoimaargumentaatio: analyysi suomalaisesta ydinvoimakeskustelusta (Arguments for and against Nuclear Energy: An Analysis of the Finnish Discussion over Nuclear Energy). Tampereen yliopiston yhteiskuntatieteiden tutkimuslaitos, sarja B:47.

Tarde, Gabriel ([1898] 1969) Opinion and Conversation. In Gabriel Tarde, On Communication and Social Influence (ed. by Terry N. Clark) 297-318. Chicago: The University of Chicago Press.

Tarde, Gabriel ([1901] 1969) The Public and the Crowd. In Gabriel Tarde, On Communication and Social Influence (ed. by Terry N. Clark) 277-294. Chicago: The University of Chicago Press.

Troyer, Ronald J. (1989) Are Social Problems and Social Movements the Same Thing? In James A. Holstein and Gale Miller (eds.) Perspectives on Social Problems, vol. 1, 41-58. Greenwich, CT: JAI Press.

Turner, Ralph H. and Lewis M. Killian (1972) Collective Behavior ( $2^{\text {nd }}$ edition). Englewood Cliffs, NJ: Prentice-Hall.

Virtanen, Matti (1981a) Miten arvioida valistuksen vaikutuksia? (How to Assess the Effects of Education?) Alkoholipolitiikka, 46:4, 184-191.

Virtanen, Matti (1981b) Valistuksen virittävyys: Kohtuus on olemassa -kampanja Alkon politiikan osana (The Generativity of Education: the 'Moderation Rules OK' Campaing Considered as a Part of Alko Policy). Alkoholipoliittisen tutkimuslaitoksen tutkimusseloste no. 147.

Virtanen, Matti (1984) Valistuksen vaikutukset (The Effects of Education). Tiedotustutkimus, 7:1, 12-17.

Väliverronen, Esa (1996) Ympäristöuhkan anatomia (The Anatomy of an Environmental Threat). Tampere: Vastapaino. 